ISSN 1678-3921

Journal homepage: www.embrapa.br/pab

For manuscript submission and journal contents, access: www.scielo.br/pab

\section{Difference between isolates from brown eye spot and black spot lesions in coffee plants}

\begin{abstract}
The objective of this work was to evaluate the difference between the isolates from two cercospora leaf spot symptoms (brown eye spot and black spot) in relation to conidial morphology, mycelial growth, cercosporin production, and reproduction of symptoms in coffee leaves collected in three municipalities in the state of Minas Gerais, Brazil. There was a difference between the isolates for the studied variables, but without any relation to the type of symptom. The differences found were not associated with the origin of the isolates. The symptoms characterized as black spot were associated with different host conditions during the infection process.
\end{abstract}

Index terms: Cercospora coffeicola, Coffea arabica, cercosporin production, conidial morphology, mycelial growth, reproduction of symptoms.

\section{Diferença entre isolados de lesões mancha de olho pardo e cercospora negra em cafeeiro}

Resumo - O objetivo deste trabalho foi avaliar a diferença entre isolados de dois tipos de sintomas de cercosporiose do cafeeiro (mancha de olho pardo e cercospora negra) em relação à morfologia conidial, ao crescimento micelial, à produção de cercosporina e à reprodutibilidade dos sintomas em folhas de cafeeiro coletadas em três municípios de Minas Gerais, Brasil. Observou-se diferença entre os isolados para as variáveis estudadas, mas sem relação com o tipo de sintoma. As diferenças encontradas não foram associadas à origem do isolado. Os sintomas caracterizados como cercospora negra foram associados a diferentes condições do hospedeiro durante o processo de infecção.

Termos para indexação: Cercospora coffeicola, Coffea arabica, produção de cercosporina, morfologia conidial, crescimento micelial, reprodutibilidade dos sintomas.

Cercospora leaf spot or brown eye spot (BYS) is a disease whose etiologic agent is the fungus Cercospora coffeicola Berk \& Cooke, it can be the most significant coffee disease and can lead to yield losses of up to $30 \%$. The characteristic symptoms appear on the leaves as necrotic spots with light-colored centers that are surrounded by a purplish-brown ring with yellowish edges (Souza et al., 2015). However, atypical symptoms characterized by dark spots without the yellow halo were verified in coffee plants, denominated in some regions as black spot (BS). Andrade et al. (2016) showed that both isolates of brown eye spot and black spot were able to induce alterations in the antioxidant metabolism of coffee leaves, suggesting that there are other factors leading to the black-spot-lesion type in field conditions. 
There are still doubts about the differences between the isolates responsible for the symptoms of brown eye spot or black spot symptons, as they produce different symptoms in the coffee plants.

The objective of this work was to evaluate the difference between the isolates from two cercospora leaf spot symptoms (brown eye spot and black spot) in relation to conidial morphology, mycelial growth, cercosporin production, and reproduction of symptoms in coffee leaves collected in three municipalities in the state of Minas Gerais, Brazil.

Leaves of coffee 'Mundo Novo IAC 376-4' showing brown eye spot (BYS) and black spot (BS) symptoms were collected from farms in the municipalities of Bonfinópolis de Minas, São Sebastião do Paraíso, and Três Pontas, in the state of Minas Gerais, in May 2012. Conidia were isolated using the method proposed by Santos et al. (2014). After obtaining monosporic cultures, the isolates were identified as LFP 37, LFP 18, and LFP 26 (BYS symptoms) and LFP 36, LFP 19, and LFP 56 (BS symptoms), in samples collected in Bonfinópolis de Minas (LFP 37 and LFP 36), São Sebastião do Paraíso (LFP 18 and LFP 19), and Três Pontas (LFP 26 and LFP 56).

Slides of the six isolates were mounted to be observed under a DM 2000 (Leica) epifluorescence microscope with $40 \mathrm{X}$ magnification, in order to measure the conidia (length and width). Conidia were obtainde from in vitro sporulation (Souza et al., 2012). The experimental design was completely randomized, with six treatments (isolates) and five replicates, with 20 conidia measured per replicate.

The mycelial growth (MG) of C. coffeicola isolates was evaluated in three culture media: MEA ( $2 \%$ malt extract agar), PDA (potato dextrose agar), and V8 $(100 \mathrm{~mL} \mathrm{V8} \mathrm{liquid,} 2 \mathrm{~g}$ calcium carbonate and

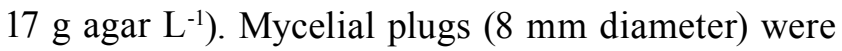
transferred to the center of Petri dishes containing $20 \mathrm{~mL}$ culture media and incubated at $25^{\circ} \mathrm{C}$ for a 12-hour photoperiod. To assess the mycelial growth, the diameter of colonies was measured in orthogonal position every three days for 21 days, with a total of seven evaluations.

The cercosporin production (CP) was evaluated by the method proposed by Jenns et al. (1989). The $C$. coffeicola isolates were undercut and transferred to the same three culture media (MEA, PDA, and V8).
The isolates were incubated for 21 days at $25^{\circ} \mathrm{C}$, and subjected to a 12-hour photoperiod.

To assess MG and to quantify the $\mathrm{CP}$, a randomized complete block design was carried out, with four replicates per isolate, in which each plate was considered an experimental unit. The analysis of variance design was factorial a $6 \times 3$ factorial arrangement, consisting of six isolates and three culture media.

To evaluate the reproducibility of the symptoms and the severity of the disease caused by the different C. coffeicola isolates, were utilized two coffee susceptible cultivars were used - Mundo Novo 376-4 and Iapar 59 -, with four pairs of leaves. In order to obtain conidia of the isolates, the method proposed by Souza et al. (2012) was used. The suspension was adjusted to the concentration of $3 \times 10^{4}$ conidia $\mathrm{mL}^{-1}$ and used to inoculate all the leaves of the plant. After the onset of symptoms, four severity assessments were carried out at seven-day intervals. The severity was determined by diagrammatic scale (Custódio et al., 2011). The area under the disease severity progress curve (AUSPC) was calculated according to Shaner \& Finney (1977). This trial was conducted in a randomized complete block design, with four replicates, and three plants per plot. The analysis of variance was performed in a $6 \times 2$ factorial arrangement consisting of six isolates and two coffee cultivars.

All significant variables by the $\mathrm{F}$ test, at $5 \%$ probability, were analyzed by Tukey's test, at 5\% probability, using the Sisvar software (Ferreira, 2011).

No significant differences were found for conidial size between both Cercospora leaf spot symptoms in the isolates (Table 1), despite the largest length of LFP $18(148.6 \mu \mathrm{m})$, and the smaller sizes of some isolates which varied between 69.6 and $100.66 \mu \mathrm{m}$. That is, there was a wide range of conidia lengths, which have already been observed in other studies on Cercospora (Yeh \& Sinclair, 1980) and Pseudocercospora genera (Nakashima et al., 2016). However, in the current work, conidia of all isolates showed similar width that ranged from 2.42 to $3.30 \mu \mathrm{m}$.

For mycelial growth, the rate index (MGRI) and the interaction isolates $\times$ culture media were significant (Table 1). The highest MGRI was shown by LFP 19 cultivated in MEA medium, followed by LFP 36 and LFP 56 in PDA. All isolates showed similar MGRI in V8 medium. Similarly, Dell'Acqua et al. (2011) 
reported this variability for the mycelial growth of $C$. coffeicola isolates.

For mycelial growth, the rate index (MGRI) and the interaction isolates $\times$ culture media were significant (Table 1). The highest MGRI was shown by LFP 19 cultivated in MEA medium, followed by LFP 36 and LFP 56 in PDA. All isolates showed similar MGRI in V8 medium. Similarly, Dell'Acqua et al. (2011) reported this variability for the mycelial growth of C. coffeicola isolates.

There was also a significant interaction between the isolates $\times$ culture media for CP (Table 1$)$. The highest toxin production occurred in the isolates LFP 18, LFP 26, and LFP 56 in the culture media MEA; and LFP 26, LFP 37, and LFP 56 in the culture media PDA. The isolates did not differ significantly for $\mathrm{CP}$ when cultured in V8 medium, as observed in the MGRI. According to Daub \& Cheung (2007), culture media with nutritive conditions, such as the V8, to stimulate sporulation in species of the genus Cercospora, reduce the synthesis of cercosporin.

The interaction isolates $\times$ cultivars was not significant for the AUSPC. The isolates LFP 18, LFP19, and LFP 56 showed higher AUSPC in 'Mundo Novo IAC 376-4' (Table 1). The isolates LFP 18 and LFP 19 showed the highest AUSPC in 'Iapar 59'. Differences were observed between the isolates for disease severity, however, without differentiating between both types of the evaluated symptoms.

When infected with all the tested isolates, both cultivars developed typical symptoms of brown eye spot, which show necrotic points with light-colored centers surrounded by a purple-brown ring with yellow halos, which means that possibly the variability of the symptoms is due to the different responses of the host to the pathogen, and not to the pathogen itself. Similar results were found in the study by Andrade et al. (2016), in which isolates of brown eye spot and black spot inoculated in coffee seedlings 'Mundo Novo IAC 376-4' produced lesions of the common type (brown eye spot). The severity variation of Cercospora leaf spot in different coffee cultivars has been reported by other authors (Patricio et al., 2010; Souza et al., 2012). As in the cultivars Mundo Novo IAC 376-4 and Iapar 59 are from different genetic origins and showed interactions between pathogen, host, and environment in the disease symptoms, the observed variation can be attributed to the severity of Cercospora leaf spot.

The isolates studied herein showed differences for conidia size, mycelial growth, production of cercosporin, and severity of brown eye spot in 'Mundo Novo IAC 376-4' and 'Iapar 59' coffee seedlings,

Table 1. Length and width of conidia, variance size of length and width of conidia, mycelial growth, cercosporin concentration of $C$. coffeicola isolates obtained from leaves with brown spot eye and black spot symptoms grown under PDA, MEA and V8 culture media, and area under the severity progress curve (AUSPC) evaluated in coffee seedlings of two cultivars ${ }^{(1)}$.

\begin{tabular}{|c|c|c|c|c|c|c|c|c|c|c|c|c|}
\hline \multirow[t]{2}{*}{ Isolate } & \multirow{2}{*}{$\begin{array}{l}\text { Length } \\
(\mu \mathrm{m})^{(2)}\end{array}$} & \multirow[t]{2}{*}{ Variance } & \multirow{2}{*}{$\begin{array}{l}\text { Width } \\
(\mu \mathrm{m})\end{array}$} & \multirow{2}{*}{$\begin{array}{l}\text { Vari- } \\
\text { ance }\end{array}$} & \multicolumn{3}{|c|}{ Mycelial growth $(\mathrm{cm})$} & \multicolumn{3}{|c|}{ Cercosporin $\left(\mathrm{nmol} \mathrm{mL}^{-1}\right)^{(2)}$} & \multicolumn{2}{|c|}{ AUSPC } \\
\hline & & & & & PDA & MEA & V8 & PDA & MEA & V8 & Mundo Novo & Iapar 59 \\
\hline & \multicolumn{12}{|c|}{ Brown eye spot } \\
\hline LFP 18 & $148.60 \mathrm{a}$ & $\begin{array}{c}100.25- \\
193.83\end{array}$ & $3.06 \mathrm{a}$ & $\begin{array}{c}2.41- \\
3.78\end{array}$ & $2.34 \mathrm{aA}$ & $2.35 \mathrm{aA}$ & $2.41 \mathrm{aA}$ & $4.56 \mathrm{aA}$ & $13.46 \mathrm{bB}$ & $3.33 \mathrm{aA}$ & $149.86 \mathrm{~b}$ & $241.25 b$ \\
\hline LFP 26 & $103.71 \mathrm{c}$ & $\begin{array}{c}87.83- \\
122.8\end{array}$ & $2.42 \mathrm{a}$ & $\begin{array}{c}2.22- \\
2.77\end{array}$ & $2.27 \mathrm{aA}$ & $2.44 \mathrm{aA}$ & $2.38 \mathrm{aA}$ & $8.31 \mathrm{bB}$ & $10.13 \mathrm{bB}$ & $2.91 \mathrm{aA}$ & $120.92 b$ & $143.78 \mathrm{a}$ \\
\hline \multirow[t]{2}{*}{ LFP 37} & $69.61 \mathrm{c}$ & $\begin{array}{c}57.89- \\
79.46\end{array}$ & $2.59 \mathrm{a}$ & $\begin{array}{c}2.14- \\
2.99\end{array}$ & $2.43 \mathrm{aA}$ & $2.34 \mathrm{aA}$ & $2.40 \mathrm{aA}$ & $10.42 \mathrm{bB}$ & $7.26 \mathrm{aB}$ & $2.02 \mathrm{aA}$ & $48.67 \mathrm{a}$ & $75.66 \mathrm{a}$ \\
\hline & \multicolumn{12}{|c|}{ Black spot } \\
\hline LFP 19 & $84.81 \mathrm{c}$ & $\begin{array}{c}54.22- \\
121.4\end{array}$ & $3.02 \mathrm{a}$ & $\begin{array}{c}1.83- \\
4.50\end{array}$ & $2.37 \mathrm{aA}$ & $2.81 \mathrm{bB}$ & $2.46 \mathrm{aA}$ & $3.27 \mathrm{aA}$ & $2.29 \mathrm{aA}$ & $1.31 \mathrm{aA}$ & $154.98 \mathrm{~b}$ & $229.36 b$ \\
\hline LFP 36 & $100.66 \mathrm{c}$ & $\begin{array}{l}95.06- \\
105.73\end{array}$ & $3.30 \mathrm{a}$ & $\begin{array}{c}2.78- \\
4.24\end{array}$ & $2.70 \mathrm{bA}$ & $2.43 \mathrm{aB}$ & $2.58 \mathrm{aA}$ & $3.90 \mathrm{aA}$ & $4.92 \mathrm{aA}$ & $3.69 \mathrm{aA}$ & $85.99 \mathrm{a}$ & $106.57 \mathrm{a}$ \\
\hline LFP 56 & $127.62 \mathrm{~b}$ & $\begin{array}{c}106.11- \\
154.64\end{array}$ & $2.73 \mathrm{a}$ & $\begin{array}{c}1.92- \\
3.56\end{array}$ & $2.52 \mathrm{bA}$ & $2.50 \mathrm{aA}$ & $2.44 \mathrm{aA}$ & $10.61 \mathrm{bB}$ & $10.00 \mathrm{bB}$ & $2.48 \mathrm{aA}$ & $134.00 \mathrm{~b}$ & $112.63 \mathrm{a}$ \\
\hline
\end{tabular}

(1)Means followed by equal letters, lowercase on the column and uppercase on the row (within MGRI or cercosporin), do not differ by Scott-Knott's test, at $5 \%$ probability. ${ }^{(2)}$ Data transformed into $(x+1.0)^{1 / 2}$. 
but these differences were not related to the type of cercosporiosis lesions - brown eye spot or black spot in the places from where they were obtained. Different symptoms observed in field conditions may be due to differences in the hosts and environmental conditions prevailing in the coffee crops in the places from which they were collected.

\section{Acknowledgments}

To Conselho Nacional de Desenvolvimento Científico e Tecnológico (CNPq), Programa Nacional de Pesquisa e Desenvolvimento do Café (CBP\&D/ Café), Instituto Brasileiro de Ciência e Tecnologia do Café (INCT Café/CNPq), to Coordenação de Aperfeiçoamento de Pessoal de Nível Superior (Capes), and to Fundação de Amparo à Pesquisa do Estado de Minas Gerais (Fapemig), for financial support.

\section{References}

ANDRADE， C.C.L. de; VICENTIN， R.P.; COSTA， J.R.; PERINA, F.J.; RESENDE, M.L.V. de; ALVES, E. Alterations in antioxidant metabolism in coffee leaves infected by Cercospora coffeicola. Ciência Rural, v.46, p.1764-1770, 2016. DOI: https://doi.org/10.1590/0103-8478cr20150938.

CUSTÓDIO, A.A. de P.; POZZA, E.A.; GUIMARÃES, S. da S.C.; KOSHIKUMO, E.S.M.; AGREDO HOYOS, J.M.; SOUZA, P.E. de. Comparison and validation of diagrammatic scales for brown eye spots in coffee tree leaves. Ciência e Agrotecnologia, v.35, p.1067-1076, 2011. DOI: https://doi.org/10.1590/S141370542011000600005 .

DAUB, M.E.; CHUNG, K.-R. Cercosporin: a photoactivated toxin in plant disease. APSnet Feature, p.1-12, 2007. DOI: https://doi.org/10.1094/APSnetFeature/2007-0207.

DELL'ACQUA, R.; MANTOVANI, E.S.; BRAGHINI, M.T.; OLIVEIRA, C.M.G.; HARAKAVA, R.; ROBAINA, A.S.; PETEK, M.R.; PATRICIO, F.R.A. Variabilidade in vitro, in vivo e molecular de isolados de Cercospora coffeicola. Tropical Plant
Pathology, v.36, p.313-326, 2011. DOI: https://doi.org/10.1590/ S1982-56762011000500007.

FERREIRA, D.F. Silvar: a computer statistical analysis system. Ciência \& Agrotecnologia, v.35, p.1039-1042, 2011. DOI: https://doi.org/10.1590/S1413-70542011000600001.

JENNS, A.E.; DAUB, M.E.; UPCHURCH, R.G. Regulation of cercosporin accumulation in culture by medium and temperature manipulation. Phytopathology, v.79, p.213-219, 1989. DOI: https://doi.org/10.1094/Phyto-79-213.

NAKASHIMA, C.; MOTOHASHI, K.; CHEN, C.-Y.; GROENEWALD, J.Z.; CROUS, P.W. Species diversity of Pseudocercospora from Far East Asia. Mycological Progress, v.15, p.1093-1117, 2016. DOI: https://doi.org/10.1007/s11557-0161231-7.

PATRICIO,F.R.A.; BRAGHINI, M.T.; FAZUOLI,L.C. Resistência de plantas de Coffea arabica, Coffea canephora e híbridos interespecíficos à cercosporiose. Bragantia, v.69, p.883-890, 2010. DOI: https://doi.org/10.1590/S0006-87052010000400014

SANTOS, L.A.; SOUZA, P.E. de; POZZA, E.A.; CALDEIRA, D.M.; BOTELHO, D.M. dos S. Nova técnica para isolar Cercospora coffeicola Berkeley \& Cooke, agente etiológico da cercosporiose do cafeeiro. Coffee Science, v.9, p.142-144, 2014. DOI: https://doi.org/10.25186/cs.v9i1.535.

SHANER, G.; FINNEY, R.E. The effect of nitrogen fertilization on the expression of slow-mildwing resistance in knox wheat. Phytopathology, v.67, p.1051-1056, 1977. DOI: https://doi.org/10.1094/Phyto-67-1051.

SOUZA, A.G.C.; MAFFIA, L.A.; MIZUBUTI, E.S.G. Cultural and aggressiveness variability of Cercospora coffeicola. Journal of Phytopathology, v.160, p.540-546, 2012. DOI: https://doi.org/10.1111/j.1439-0434.2012.01947.x.

SOUZA, A.G.C.; MAFFIA, L.A.; SILVA, F.F.; MIZUBUTI, E.S.G.; TEIXEIRA, H. A time series analysis of brown eye spot progress in conventional and organic coffee production systems. Plant Pathology, v.64, p.157-166, 2015. DOI: https://doi.org/10.1111/ppa.12250.

YEH, C.C.; SINCLAIR, J.B. Sporulation and variation in size of conidia and conidiophores among five isolates of Cercospora kikuchii. Plant Disease, v.64, p.373-374, 1980. DOI: https://doi.org/10.1094/PD-64-373. 